Vol. VIII No. 1, April 2015

P-ISSN: $1979-858 \mathrm{X}$

Halaman $39-46$

\title{
PENGARUH INVESTMENT OPPORTUNITY SET, STRUKTUR MODAL, PERTUMBUHAN PERUSAHAAN, DAN RETURN ON ASSET TERHADAP NILAI PERUSAHAAN
}

\author{
Gita Syardiana \\ Ahmad Rodoni \\ Zuwesty Eka Putri \\ UIN Syarif Hidayatullah Jakarta
}

\begin{abstract}
The purposes of this research to analyze the effects of investment opportunity set (IOS), structure capital, growth, and return on asset (ROA) to firm's value. This research used all the companies listed on Indonesian Exchange in the peroid 2012 until 2014. The number of all companies that were became in this study were 119 companies with 3 year observation. Based on method purposive sampling, research sample total is 357 financial statements and annual report. Data analyzed by regression data panel. Result of this research indicates that investment opportunity set (IOS), growth, and return on asset (ROA) influences significantly positive on the firm value, while structure capital does not influences to firm value.
\end{abstract}

Keywords: Investment Opportunity Set (IOS), Structure Capital, Growth, Return On Asset (ROA), Firm Value

ABSTRAK: Penelitian ini bertujuan untuk menganalisis pengaruh investment opportunity set (IOS), struktur modal, pertumbuhan perusahaan, return on asset (ROA) terhadap nilai perusahaan. Penelitian ini menggunakan sampel seluruh perusahaan yang terdaftar di Bursa Efek Indonesia selama periode 2012 sampai 2014. Jumlah seluruh perusahaan yang dijadikan sampel penelitian ini adalah 119 perusahaan dengan pengamatan selama 3 tahun. Berdasarkan metode purposive sampling, total sampel penelitian adalah 357 laporan keuangan dan laporan tahunan. Pengujian hipotesis dalam penelitian ini menggunakan metode analisis regresi data panel. Hasil penelitian menunjukkan bahwa investment opportunity set (IOS), pertumbuhan perusahaan, dan return on asset (ROA) berpengaruh signifikan terhadap nilai perusahaan, sedangkan struktur modal tidak berpengaruh signifikan terhadap nilai perusahaan.

Kata Kunci: Investment Oportunity Set (IOS), Struktur Modal, Pertumbuhan Perusahaan, Return On Asset (ROA), Nilai Perusahaan

\footnotetext{
${ }^{1}$ Draft pertama: 15 Desember 2014; Revisi: 17 Januari 2015; Diterima: 10 Februari 2015 Penulis dapat dikontak melalui: doni_ahmad@yahoo.com
} 


\section{PENDAHULUAN}

Pada hakikatnya pendirian sebuah perusahaan haruslah memiliki tujuan yang jelas. Ada beberapa hal yang mengemukakan tentang tujuan pendirian suatu peruahaan. Tujuan perusahaan yang pertama adalah untuk mencapai keuntungan maksimal atau laba yang sebesar-besarnya. Tujuan perusahaan yang kedua adalah ingin memakmurkan pemilik perusahaan atau para pemilik saham. Sedangkan tujuan perusahaan yang ketiga adalah memaksimalkan nilai perusahaan yang tercermin pada harga sahamnya. Ketiga tujuan perusahan tersebut sebenarnya secara substansial tidak banyak berbeda. Hanya saja penekanan yang ingin dicapai oleh masing-masing perusahaan berbeda antara satu dengan yang lainnya (Martono dan Agus, 2005).

Harga pasar saham juga menunjukkan nilai perusahaan. Bila harga saham meningkat maka dapat diartikan nilai perusahaan meningkat dan kesejahteraan pemilik meningkat. Semakin tinggi harga saham semakin tinggi nilai perusahaan. Nilai perusahaan yang tinggi menunjukkan tingkat kemakmuran pemegang saham juga tinggi. Kekayaan pemegang saham dan perusahaan dipresentasikan oleh harga saham yang merupakan cerminan dari keputusan investasi, pendanaan (financing), dan manajemen asset (Sri Hermuningsih, 2013)

Myers (1977) dan Hasnawati (2005) memperkenalkan set peluang investasi (investment opportunity set) dalam kaitannya untuk mencapai tujuan perusahaan. Menurut mereka investment opportunity set (IOS) memberikan petunjuk yang lebih luas dimana nilai perusahaan sebagai tujuan utama tergantung pada pengeluaran perusahaan di masa yang akan datang. Investment opportunity set (IOS) merupakan suatu kombinasi antara aktiva yang dimiliki (asset in place) dan pilihan di masa yang akan datang dengan net present value positf. IOS dari suatu perusahaan juga dapat mempengaruhi cara pandang manajer, pemilik, investor, dan kreditr terhadap perusahaan. Perusahaan yang mempunyai kesempatan tumbuh tinggi dianggap dapat menghasilkan return yang tinggi pula (Wiranto dan Rusiti, 2013).

\section{KERANGKA TEORITIS DAN PENGEMBANGAN HIPOTESIS}

Teori struktur modal menjelaskan bahwa kebijakan pendanaan (financial policy) perusahaan dalam menentukan struktur modal (bauran antara hutang dan ekuitas) bertujuan untuk mengoptimalkan nilai perusahaan (value of the firm). Penggunaan hutang sebagai sumber pendanaan perusahaan memiliki keuntungan dan kerugian. Keuntungan penggunaan hutang diperoleh dari pajak (bunga hutang adalah pengurangan pajak) dan disiplin manajer (kewajiban membayar hutang menyebabkan disiplin manajemen), sedangkan kerugian penggunaan hutang berhubungan dengan timbulnya biaya keagenan dan biaya kepailitan (Hermuningsih, 2013).

Pertumbuhan perusahaan (growth) adalah seberapa jauh perusahaan menempatkan diri dalam sistem ekonomi secara keseluruhan atau sistem ekonomi untuk industri yang sama (Machfoedz, 1996). Pertumbuhan peusahaan (growth) adalah seberapa jauh perusahaan menempatkan diri dalam system ekonomi secara keseluruhan atau system ekonomi untuk industri yang sama. Pada umumnya, perusahaan yang tumbuh dengan cepat memperoleh hasil yang positif. Pertumbuhan cepat juga memaksa sumber daya manusia yang dimiliki untuk secara optimal memberikan kontribusinya (Kadek, 2011).

Profitabilitas adalah rasio dari efektifitas manajemen berdasarkan hasil pengembalian yang dihasilkan dari penjualan dan investasi. Rasio profitabilitas terdiri dari profit margin, basic earning power, return on asset (ROA), dan return on equity (ROA) (Hermuningsih, 2013). ROA merupakan rasio yang menunjukkan kemampuan perusahaan dalam menghasilkan laba bersih dengan menggunakan total asset. Semakin besar hasil ROA maka kinerja perusahaan semakin baik. Adanya pertumbuhan ROA menunjuukkan prospek perusahaan yang semakin baik karena adanya potensi keuntungan yang diperoleh perusahaan.Berdasarkan uraian yang telah dijelaskan diatas, maka peneliti bertujuan untuk 
meneliti pengaruh investment opportunity set (ROA), struktur modal, pertumbuhan perusahaan, dan return on asset (ROA) terhadap nilai perusahaan.

\section{Pengaruh Investment Opportunity Set (IOS) terhadap Nilai Perusahaan}

Beberapa studi yang dilakukan dalam hubungannya dengan keputusan investasi antara lain oleh Myers (1977) yang memperkenalkan IOS. IOS memberi petunjuk yang lebih luas dimana nilai perusahaan tergantung pada pengeluaran perusahaan di masa yang akan datang. Jadi prospek perusahaan dapat ditaksir dari Investment Opportunity Set (IOS). IOS didefinisikan sebagai kombinasi antara aktiva yang dimiliki (assets in place) dan pilihan investasi di masa yang akan datang dengan net present value positif. Dengan demikian keterkaitan antara investment opportunity set (IOS) dengan nilai perusahaan dapat dirumuskan melalui hipotesis sebagai berikut:

$\mathbf{H a}_{\mathbf{1}}$ : IOS berpengaruh positif terhadap nilai perusahaan.

\section{Pengaruh Struktur Modal terhadap Nilai Perusahaan}

Struktur modal terkait dengan harga saham. Aturan struktur finansial konservatif menghendaki agar perusahaan tidak mempunyai hutang yang lebih besar daripada jumlah modal sendiri, dalam keadaan bagaimanapun. Pada sisi lain, konsep cost off capital menyatakan bahwa perusahaan akan berusaha untuk memperoleh struktur modal yang dapat meminimumkan biaya penggunaan modal rata-rata. Minimalisasi biaya modal ratarata ini tidak mengharuskan komposisi jumlah modal eksternal yang lebih sedikit dari jumlah modal sendiri. Dengan demikian keterkaitan antara struktur modal dengan nilai perusahaan dapat dirumuskan melalui hipoestis sebagai berikut:

$\mathbf{H a}_{2}$ : Struktur Modal berpengaruh positif terhadap nilai perusahaan.

\section{Pengaruh Pertumbuhan Perusahaan terhadap Nilai Perusahaan}

Pertumbuhan perusahaan sangat diharapkan oleh pihak internal maupun eksternal suatu perusahaan karena dapat memberikan suatu aspek yang positif bagi mereka. Dari sudut pandang investor, pertumbuhan suatu perusahaan merupakan tanda bahwa perusahaan memiliki aspek yang menguntungkan dan mereka mengharapkan rate of return (tingkat pengembalian) dari investasi mereka memberi hasil yang lebih baik (Sriwardany, 2007). Dengan demikian, keterkaitan antar pertumbuhan perusahaan dengan nilai perusahaan dapat dirumuskan sebagai berikut:

$\mathbf{H a}_{3}$ : Pertumbuhan perusahaan berpengaruh positif terhadap nilai perusahaan

\section{Pengaruh Return On Asset (ROA) Terhadap Nilai Perusahaan}

Menurut Hanafi dan Hakim (2004) return on asset (ROA) adalah rasio yang mengukur kemampuan perusahaan yang menghasilkan laba dengan menggunakan total asset (kekayaan) yang dipunyai perusahaan setelah disesuaikan dengan biaya-biaya untuk mendanai asset tersebut. Hasil pengembalian investasi yang diukur dari laba bersih setelah pajak terhadap total asset menunjukkan produktivitas dari seluruh kinerja peusahaan. Semakin kecil atau rendah rasio ini maka akan semakin kurang baik kinerja peusahaannya. Demikian pula sebaliknya apabila semakin besar atau tinggi rasio ini maka akan semakin baik kinerja perusahaan. Dengan demikian, keterkaitan antar Profitabilitas dengan nilai perusahaan dapat dirumuskan melalui hipotesis sebagai berikut:

$\mathrm{Ha}_{4}$ : Profitabilitas berpengaruh positif dengan nilai perusahaan.

Investment Opportunity Set (IOS), Struktur Modal, Pertumbuhan Perusahaan, dan Return On Asset (ROA) dengan Nilai Perusahaan

Menurut penelitian yang dilakukan Eno Fuji Astriani (2013) menyatakan bahwa IOS berpengaruh signifikan terhadap nilai perusahaan. Penelitian yang dilakukan Mahatma 
Dewi dan Wirajaya (2013) menyatakan struktur modal berpengaruh positif terhadap nilai perusahaan. Dalam penelitian yang dilakukan Sriwardany (2007) menyatakan bahwa pertumbuhan perusahaan berpengaruh positif terhadap nilai perusahaan.Adapun penelitian yang dilakukan oleh Hayati dan Ayem (2014) menyatakan bahwa ROA berpengaruh positif terhadap nilai perusahaan.Dengan demikian keterkaitan antara faktorfaktor yang mempengaruhi nilai perusahaan dapat dirumuskan dengan hipotesis sebagai berikut:

Ha $_{5}$ : investment opportunity set, struktur modal, pertumbuhan perusahaan, dan return on asset berpengaruh terhadap nilai perusahaan.

\section{METODE PENELITIAN}

Penelitian ini menggunakan model regresi data panel untuk keperluan estimasi. Penelitian ini menggunakan 1 (satu) variabel dependent yaitu nilai perusahaan dan 4 (empat) variabel independent (bebas) yaitu investment opportunity asset (IOS), struktur modal, pertumbuhan perusahaan, dan return on asset (ROA). Data yang digunakan adalah data sekunder. Analisis dalam penelitian ini menggunakan Analisis Regresi Data Panel, yaitu analisis yang menggabungkan data time series dan cross section. Adapun data time series yang telah ditentukan adalah tahun 2012-2014, selain itu telah ditentukan juga data cross section yang akan diteliti meliputi 119 (seratus sembilan belas) perusahaan.

\section{a. Pemilihan Model Data Panel}

Terdapat tiga model yang dapat digunakan dalam mengestimasi data panel, yaitu: 1) pendekatan PLS (Pooled Least Square), 2) pendekatan Fixed Effect Model (FEM), 3) Pendekatan Radom Effect Model (FEM).

1. Uji Chow. Uji ini dilakukan untuk mengetahui model Pooled Least Square (PLS) atau FEM yang akan digunakan dalam estimasi. Untuk mengujinya dapat digunakan restricted F-test atau nilai probabilitas (P-Value) Jika nilai F-hitung $>$ F-tabel, atau nilai probabilitas (P-Value) < a $5 \%$, maka artinya model panel yang baik untuk digunakan adalah Fixed EffectModel, dan sebaliknya jika (P-Value) > a 5\%, maka model (PLS) yang dipakai dan dianalisis.

2. Uji Hausman. Keputusan penggunaan FEM dan REM dapat pula ditentukan dengan menggunakan spesifikasi yang dikembangkan dengan Hausman. Setelah dilakukan pengujian ini, hasil dari Hausmantest dibandingkan dengan Chi-square statistik dengan $\mathrm{df}=\mathrm{k}$, dimana $\mathrm{k}$ adalah jumlah koefesien variabel yang diestimasi atau nilai probabilitas (P-Value) < a 5\%, jika hasil dari Hausman test signifikan, maka Fixed Effect Model yang digunakan.

3. Uji Langrangge Multiliper (LM). Dilakukan untuk membandingkan atau memilih model mana yang terbaik antara PLS dan REM. Setelah dilakukan pengujian ini, hasil dari Langrangge Multiplier test (Breusch-Pagan) dibandingkan dengan nilai probability. Jika nilai Breusch - Pagan< a 5\% maka artinya model panel yang baik untuk digunakan adalah Random Effect Model (REM). Namun jika sebaliknya maka model data panel yang baik digunakan adalah Pooled Least Square (PLS).

\section{Uji Asumsi Klasik}

Pengujian asumsi klasik ini bertujuan untuk mengetahui dan menguji kelayakan atas model regresi data panel yang digunakan dalam penelitian ini. Pengujian terdiri dari uji normalitas, uji multikolenieritas, uji hetereoskedastisitas, dan uji autokorelasi.

\section{Model Persamaan Regresi Data Panel}

Model persamaan dasar data panel yaitu:

Yit $=\beta_{1}$ Xiit $+\beta_{2} X_{2} i t+\beta_{3} X_{3} i t+\beta_{4} X_{4} i t+\mu i t$. 


\section{Uji Hipotesis}
a. Uji Signifikansi Individual (uji t)
b. Uji Signifikansi simultan (uji F)
c. Koefisien Determinasi (Adjusted $\mathbf{R}^{2}$ )

\section{Variabel penelitian}

1. Variabel Independen

a. Investment Opportunity Set (IOS) ( $\left.\mathrm{X}_{1}\right)$

Pengukuran menggunakan market to book value of equity memiliki pengaruh yang besar terhadap nilai perusahaan. Penggunaan rasio ini didasari atas pemikiran MVE BVE yang mencerminkan pasar menilai return investasi dimasa depan akan lebih besar dari return yang diharapkan dari ekuitasnya. Dalam penelitian Astriani (2014), secara matematis variabel market to book value of equity diformulasikan sebagai berikut :

$$
\text { MBVE }=\frac{(\text { Jumlah Saham Beredar } x \text { Closingprice })}{\text { Total Equity }}
$$

b. Struktur Modal (X2)

Struktur modal diukur dengan debt to equity ratio (DER) adalah perbandingan total hutang yang dimiliki perusahaan dengan total ekuitas perusahaan pada seluruh perusahaan go public yang terdaftar di BEI tahun 2012 - 2014. Satuan pengukuran DER adalah dalam persentase.

$$
\text { DER }=\frac{\text { Total Debt }}{\text { Total Equity }} \quad \text { X } 100 \%
$$

c. Pertumbuhan Perusahaan $\left(\mathrm{X}_{3}\right)$

Pertumbuhan perusahaan diukur dengan menggunakan perubahan total aktiva. Pertumbuhan aktiva adalah selisih total aktiva yang dimiliki perusahaan pada periode sekarang dengan periode sebelumnya terhadap total aktiva periode sebelumnya pada pada seluruh perusahaan go public yang terdaftar di BEI tahun $2012-2014$. Satuan pengukuran perubahan total aktiva dalam persentase.

Perubahan total aktim -

$$
\text { X } 100 \%
$$

$$
\text { Total aktivat - Total aktiva t-1 }
$$

d. Return On Asset (ROA) (X4) Total aktiva t-1

Dalam penelitian ini, rasio yaıy uıuııкaı dualdı neıur' un Asset (ROA).Return On Asset (ROA) digunakan untuk mengukur efiktivitas perusahaan di dalam menghasilkan keuntungan dengan memanfaatkan aktiva yang dimilikinya.

\section{Variabel Dependen}

Variable dependen dalam perusahaan ini adalah nilai perusahaan. Nilai perusahaan diukur dengan menggunakan Tobins' q ratio (Astriani, 2013).

\section{HASIL DAN PEMBAHASAN}

Berdasarkan hasil statistik untuk pengujian model yang terdiri dari: uji chow, hausman, Langrangge Multiliper (LM) dan uji asumsi klasik terpenuhi. Setelah pengujian awal terpenuhi, baru dilakukan pengujian berikutnya. Berikut ini ditampilkan ringkasan shasil SPSS. 
Tabel 1.Ringkasan Hasil Uji Statistik

\begin{tabular}{|l|r|}
\hline \multicolumn{1}{|c|}{ Keterangan } & \multicolumn{2}{|c|}{ Hasil } \\
\hline Uji t: & .000 \\
\hline sig IOS & .297 \\
\hline sig SM & .014 \\
\hline sig Growth & .046 \\
\hline sig ROA & 1165.182 \\
\hline Uji F & 0.000000 \\
\hline F & 0.928981 \\
\hline Prob & \\
\hline Adjusted R-Squared & \\
\hline
\end{tabular}

Sumber: data diolah

Berdasarkan tabel 1 didapatkan koefisien determinasi (adjusted $R^{2}$ ) sebesar 0.928981 atau $92,89 \%$. Hal ini terlihat bahwa 92,89\% nilai perusahaan dapat dijelaskan oleh IOS, struktur modal, pertumbuhan perusahaan, dan ROA. Sedangkan 7,11\% di jelaskan oleh variabel diluar variabel independen yang digunakan, misalnya variabel ukuran perusahaan, leverage, dan variabel lainnya.

a. Pengaruh Investment Opportunity Set (IOS) Terhadap Nilai Perusahaan

Hasil pengujian hipotesis, ditemukan bahwa variabel IOS berpengaruh positif signifikan terhadap nilai perusahaan. Hal ini berarti $\mathrm{H}_{1}$ diterima, maka dapat disimpulkan bahwa IOS menunjukkan hubungan yang positif terhadap nilai perusahaan, yang dapat dimungkinkan bahwa perusahaan yang banyak melakukan investasi cenderung memiliki asset yang bertambah setiap waktu atau bertambah besar kekayaannya. Perusahaan yang bertambah besar dari waktu ke waktu akan dapat menciptakan sentiment positif para investor, sehingga harga saham pada akhirnya akan dapat meningkatkan nilai perusahaan. Hal ini mendukung pernyataan Astriani (2013) yang menyatakan bahwa IOS berpengaruh signifikan terhadap nilai perusahaan.

b. Pengaruh Struktur Modal Terhadap Nilai Perusahaan

Dalam penelitian ini, menemukan bahwa struktur modal tidak berpengaruh terhadap nilai perusahaan. Hasil ini dapat disimpulkan bahwa $\mathrm{H}_{2}$ ditolak. Hasil penelitian ini tidak mendukung trade-off theory yang menyatakan bahwa (dengan asumsi titik target struktur modal yang belum optimal) peningkatan rasio hutang pada struktur modal akan meningkatkan perusahaan. Hasil temuan ini juga konsisten dengan penelitian yang dilakukan oleh Dewi, Yuniarta, Atmadja (2014) yang menyatakan bahwa variabel struktur modal tidak mempengaruhi nilai perusahaan. Tetapi hasil penelitian ini bertentang dengan hasil penelitian yang dilakukan oleh Dewi dan Wirajaya (2013) yang menyatakan bahwa struktur modal berpengaruh secara signifikan terhadap nilai perusahaan.

c. Pengaruh Pertumbuhan Perusahaan Terhadap Nilai Perusahaan

Pada penelitian ini ditemukan bahwa variabel pertumbuhan perusahaan memiliki pengaruh positif terhadap nilai perusahaan. Hal ini berarti $\mathrm{H}_{3}$ diterima. Hasil penelitian ini mendukung penelitian yang dilakukan oleh kadek (2011), Dewi, Yuniarta, Atmadja (2014) dan Sriwardany (2006) yang menyatakan bahwa pertumbuhan perusahaan mempunyai pengaruh langsung dan positif terhadap harga saham yang akan meningkatkan nilai perusahaan.

Pertumbuhan adalah dampak atas arus dana perusahaan dari perubahan operasional yang disesbabkan oleh pertumbuhan atau penurunan volume usaha. Pertumbuhan perusahaan sangat diharapkan oleh pihak internal maupun eksternal perusahaan, karena pertumbuhan yang baik memberi tanda bagi perkembangan 
perusahaan.dari sudut pandang investor, pertumbuhan suatu perusahaan merupakan tanda perusahaan memiliki aspek yang menguntungkan, dan investor pun akan mengharapkan tingkat pengembalian (rate of return) dari investasi yang dilakukan menunjukkan perkembangan yang baik.

d. Pengaruh Return On Asset (ROA) Terhadap Nilai Perusahaan

Pada penelitian ini ditemukan bahwa return on asset (ROA) memiliki pengaruh positif terhadap nilai perusahaan. Hal ini dapat disimpulkan bahwa return on asset berpengaruh positif terhadap nilai perusahaan.hal ini berarti $\mathrm{H}_{4}$ diterima. Hasil penelitian ini mendukung penelitian yang dilakukan oleh Haryati dan Ayem (2014) yang menunjukkan bahwa return on asset (ROA) berpengaruh positif terhadap nilai perusahaan.Return on asset (ROA) yang tinggi menunjukkan prospek perusahaan yang bagus, sehingga memicu permintaan saham oleh investor. Respon positif dari investor tersebut akan meningkatkan harga sahamd dan selanjutnya akan meningkatkan nilai perusahaan.

e. Pengaruh investment opportunity set (IOS), struktur modal, pertumbuhan perusahaan, dan return on asset (ROA) terhadap nilai perusahaan.

Berdasarkan hasil penelitian ini di temukan bahwa variabel investement opportunity set (IOS), struktur modal, pertumbuhan perusahaan, dan return on asset (ROA) berpengaruh secara simultan terhadap nilai perusahaan, maka $\mathrm{H}_{5}$ diterima. Hal ini dapat disimpulkan bahwa variabel independen (investment opportunity set (IOS), struktur modal, pertumbuhan perusahaan, return on asset (ROA) secara simultan berpengaruh terhadap nilai perusahaan.

\section{SIMPULAN}

Berdasarkan pada hasil analisis pembahasan yang telah dilakukan, maka dapat diperoleh kesimpulan bahwa variabel investment opportunity set (IOS), pertumbuhan perusahaan, dan return on asset (ROA) berpengaruh signifikan positif terhadap nilai perusahaan, sedangkan variabel struktur modal tidak berpengaruh signifikan terhadap nilai perusahaan. Variabel investment opportunity set (IOS) adalah variabel independe yang paling dominan mempengaruhi nilai perusahaan, karena memiliki nilai beta paling tinggi.

\section{PUSTAKA ACUAN}

Astriani, Eno Fuji, "Pengaruh Kepemilikan Manajerial, Leverage, Profitabilitas, Ukuran Perusahaan dan Investment Opportunity Set Terhadap Nilai Perusahaan", Fakultas Ekonomi, Universitas Negeri Padang, 2013.

Dewi, Putu Yunita Saputri, Yuniarta, Gede Adi, Atmadja, Ananta Wikrama Tungga, "Pengaruh Struktur Modal, Pertumbuhan Perusahaan, dan Profitabilitas Terhadap Nilai Perusahaan Pada Perusahaan LQ 45 Di BEI Periode 2008-2012", e-Journal S1 Universitas Pendidikan Ganesha Jurusan Akuntansi S1 Vol. 2 No. 1, 2014.

Fama, Eugene F, "The Effectof a Firm's Investment and Financing Decisions on the Welfare of Its Security Holders", The American Economic Review, Vol. 68, No. 3, 1978.

Hanafi, M. Mahmud dan Abdul Hakim, "Manajemen keuangan”, Yogyakarta: BDFE, 2004.

Haryati, Winur dan Ayem, Sri, "Pengaruh Return On Asset, Debt Equity Ratio, dan Earning Per Share terhadap Nilai Perusahaan”, Jurnal Akuntansi, Vol. 2 No.1, 2014.

Hasnawati, Sri, "Dampak set peluang investasi terhadap nilai perusahaan publik di Bursa Efek Jakarta”, Jurnal Akuntansi dan Auditing Indonesia, Vol. 9 No. 2, 2005.

Hermuningsih, Sri. "Pengaruh Profitabilitas, Growth Opportunity, Struktur Modal Terhadap Nilai Perusahaan Pada Perusahaan Publik Di Indonesia”. Buletin Ekonomi dan Perbankan, 2013. 
Kadek,Dewa, "Pengaruh Struktur Modal dan Pertumbuhan Perusahaan Terhadap Profitabilitas dan Nilai Perusahaan Manufaktur di Bursa Efek Indonesia”, Program Pascasarjana Universitas Udayana, Denpasar, 2011.

Mahatma Dewi, A.S dan Wirajaya, Ayu, "Pengaruh Struktur Modal, Profitabilitas, dan Ukuran Perusahaan Terhadap Nilai Perusahaan”. E-Jurnal Akuntansi Universitas Udayana 4.2, 2013

Mahfoedz, Mas'ud, "Akuntansi Manajemen Perencanaan dan Pembuatan Keputusan Jangka Pendek”, Edisi kelima, Buku 1, Yogyakarta: STIE WIDYA WIWAHA, 1996.

Martono dan Harjito, Agus, "Manajemen Keuangan", Ekonisia, Yogyakarta, 2005.

Myers, S. C dan N.S Majluf. "Corporate Financing E Investment Decision When Firm Have Information That Investor Do Not Have". Journal of Financial Economics, 13, 1984.

Puspita, Novita Santi dan Mahfud, Kholiq. 2011, "Analisis Pengaruh Struktur Modal, Pertumbuhan Perusahaan, Ukuran Perusahaan, dan Profitabilitas Terhadap Nilai Perusahaan Pada Perusahaan Manufaktur Yang Terdaftar Di Bursa Efek Indonesia Periode 2007-2009 (Studi Kasus Pada Sektor Industri Food And Beverages)". Fakultas Ekonomi Universitas Diponegoro, 2013.

Sriwardany, "Pengaruh Pertumbuhan Perusahaan Terhadap Kebijaksanaan Struktur Modal dan Dampaknya Terhadap Perubahan Harga Saham Pada Perusahaan Manufaktur Tbk”, MEPA Ekonomi, Vol 2 No 1, 2006.

Sujoko dan U. Soebiantoro. "Pengaruh Struktur Kepemilikan Saham, Leverage, FaktorIntern dan Faktor Ekstern terhadap Nilai Perusahaan "Jurnal Manajemen dan Kewirausahaan.Vol. 9.No. 1, 2007.

Warianto,Paulina dan Rusiti, "Pengaruh Ukuran Perusahaan, Struktur Modal, Likuiditas, dan Investment Opportunity Set (IOS) terhadap Kualitas Laba Pada Perusahaan Manufaktur yang Terdaftar di BEI”, Jurnal Akuntansi, Fakultas Ekonomi, Universitas Atma Jaya Yogyakarta, 2013.

Winarno, Wing Wahyu, "Analisis Ekonometrika dan Statistika dengan Eviews, Edisi Ketiga, UPP STIM YKPN, Yogyakarta, 2011. 